\title{
Det såkaldte Fabian-projekt eller Projekt Handbuch der deutschen historischen Buchbestände
}

af bibliotekskonsulent, dr.theol. Jakob H. Grønbæk

Det er nok ikke helt usandsynligt, at en læser straks vil udbryde opgivende: "Endnu et af disse evindelige projekter!!" Men måske kan det berolige en sådan læser med det samme at få at vide, at igangsætteren af netop det projekt, der skal præsenteres i det følgende, ikke skal søges blandt professionelle biblioteksfolk, men blandt kvalificerede biblioteksbenyttere. Og måske vil den pågældende læser efter den oplysning en kende lettet udbryde: "Så er der da chance for, der er behov for det projekt!"

Et helt kontant og opmuntrende moment skal så føjes til: Den lille danske andel i dette store og kostbare tyske projekt er $\emptyset$ konomisk omkostningsfrit for Det kongelige Bibliotek, som ganske naturligt har fået ansvaret for en dansk medvirken. På Det kongelige Bibliotek har man nemlig allerede i godt et år og uden stor ståhej arbejdet på projektet, og udgifterne dækkes altså ikke ved et greb i bibliotekets så sørgeligt slunkne kasse. Ganske rimeligt iøvrigt, al den stund projektet jo er tysk. Men på forhånd har det kunnet forudses, at projektet også i flere henseender vil komme Det kongelige Bibliotek til nytte, og dermed danske biblioteker og forskere.

Projektmageren er en tysk professor, dr.phil.habil. Berhard Fabian. Han er tilknyttet Englisches Seminar ved Westfälische Wilhelms-Universität i Münster. Samme dr. Fabian er en krativ og dynamisk forsker med en stor videnskabelig produktion bag sig både inden for sit egentlige fagområde, anglistikken, og inden for bog- og biblioteksvæsen. (Det kan man få syn for i REX og ved et supplerende opslag i Kürschners Gelehrten-Kalender). Og dr. Fabian kender sine biblioteker, og han har om nogen ord for at kende en forskers behov for litteratur. 
Pengene til Fabian-projektet kommer fra Vokswagen-Stiftung. Og til dækning af den danske medvirken i projektet har Det kongelige Bibliotek fra samme fond den 21. maj 1990 modtaget en bevilling på 80.000 DM. Det tyske og altså fondsst $\varnothing t t e d e$ projekt, som vi således er koblet på, åbner i sine pespektiver for en mærkbart smidigere tilgang til den ældre tyske bogproduktion - til benefice for den internationale humanistiske forskning.

I tilgift kommer så, at projektet som biprodukt kan tilføre Det kongelige Bibliotek særdeles nyttig nyorientering i retning af et mere nuanceret indblik i sammensætningen og omfanget af bibliotekets værdifulde aldre samlinger, såvel de danske (i nationalbiblioteket), de udenlandske (i universitetsbiblioteket) som de museale (i Danmarks Bogmuseum).

Hvad Bernhard Fabian har opmærksomheden rettet mod, er netop de ældre, "historiske", tyske bøger, mere præcist: bogsamlinger ("Bestände"), som indeholder bøger trykt op til år 1900. (Det drejer sig altså ikke om nok en bibliografi!) I $\varnothing$ vrigt kan det betragtes som noget opløftende, at det for en gangs skyld ikke er moderne litteratur, opmærksomheden rettes mod, men "gammeldags" trykte bøger. Sådanne bøger har nemlig også interesse for forskningen!

\section{Projektets forudsætninger}

Hvorfor interesserer Fabian-projektet sig overhovedet for "historiske" bogsamlinger med tysk litteratur? Det kræver nærmere forklaring.

I Tyskland findes der intet nationalbibliotek for den trykte litteratur fra bogtrykkerkunstens opfindelse til i dag - som f.eks. i England (British Library), i Frankrig (Bibliothèque Nationale) og i Danmark (Det kongelige Bibliotek). Denne mangel hænger sammen med tysk histories og dermed kulturhistories regionale orientering. Den tysk nationale trykte litteratur (den der altså ikke gik tabt under 2. verdenskrig) er således i dag bevaret i allehånde større eller mindre biblioteker i de enkelte Länder. Ganskevist har der været ansatser til dannelse af et tysk nationalbibliotek, således i 1871 (Die Königliche Bibliothek i Berlin), i 1913 (Deutsche Bücherei i Leipzig) og i 1946 (Deutsche Bibliothek i Frankfurt a. M. for Bundesrepublik Deutschland). Men ingen af disse biblioteker supplerede, systematisk og retrospektivt, ny trykt litteratur med gammel. Den "historiske" del af tysk national bogproduktion er således spredt over det ganske Tyskland - ja, adskilligt må man tage uden for Tyskland for at finde, f.eks. til Danmark. Dertil kan føjes, at katalogiseringsniveauet i Tyskland for den ældre tyske litteraturs vedkommende betragtes som lavere end $i$ andre lande. 
Det faktum, at der således aldrig i Tyskland har eksisteret et nationalbibliotek i egentlig forstand, har selvsagt heller ikke været befordrende for hurtig og effektiv litteratursøgning og -forsyning, når det gælder tyske "historiske" bøger.

Den historisk betingede pluralistiske tyske biblioteksstruktur har imidlertid fornylig (også på Bernhard Fabians initiativ) tilnærmet sig den i de fleste andre lande. I 1989 blev der (også med støtte fra Volkswagen-Stiftung) endelig taget et afgørende skridt til dannelse af (ikke mindre end) 5 tyske nationalbiblioteker i Vesttyskland, som hver har fået ansvaret for en retrospektiv periodebestemt litteraturdækning. (At starte på en frisk med etablering af ét nationalbibliotek blev altså anset for helt urealistisk.) Således har Herzog August Bibliothek i Wolfenbüttel fået status som tysk nationalbibliotek for det 17. århundredes bogproduktion, som det altså er blevet dette biblioteks ansvar retrospektivt at anskaffe i orginaludgaver eller i micro. De fire andre nationalbiblioteker ligger i München (ansvarlig for perioden 1450-1600), Göttingen (18. århundrede), Frankfurt a.M. (1801-70) og Berlin (for 18711945).

Men fire år forinden havde Berhard Fabian startet projektet:

Handbuch deutscher historischer Buchbestände in der Bundesrepublik Deutschland und in West-Berlin

Den 10. juli 1989 modtog Det kongelige Biblioteks overbibliotekar et brev fra professor Fabian, som havde vedlagt en "Zwischenbericht" om dette i 1984 startede tyske "Handbuch"-projekt. (DF-Revy har iøvrigt i 1990 nr. 7, s. $187-8$, bragt en kort præsentation af projektet ved Morten Hein.) I sit brev til Erland Kolding Nielsen fremhæver Fabian, at både udgivelseskomitéen af "Handbuch" og Volkswagen-Stiftung af forskere og biblioteker var blevet tilskyndet til at udvide projektet til også at omfatte biblioteker og samlinger i ikke-tysksprogede områder, hvad netop dannede baggrunden for Fabians henvendelse til Det kongelige Bibliotek om at være med. Fabian skriver, at han allerede har haft kontakt med cheferne for nationalbiblioteket i Sverige, for universitetsbibliotekerne i Uppsala og Helsinki, og at man har udtrykt interesse for projektet. Uden for Tyskland findes der nemlig, fremhæver Fabian, store og betydningsfulde samlinger af historisk tysk bogmateriale, som faktisk vil kunne komplettere samlingerne i de tysksprogede områder. Så sandt som det er skrevet! 
Men tilbage til det oprindeligt internt tyske projekt! I den just nævnte "Zwischenbericht" (fra 1987) gives der en grundig beskrivelse af projektet, af dets indhold og sigte, forudsætninger og organisation. "Neben Bibliographien und Katalogen", hedder det bl.a., "bildet sich seit einiger Zeit eine weitere Art der "Inventarisierung" der gedruckten Überlieferung heraus. Sie richtet sich nicht auf den einzelnen Titel, sondern sieht ihre Aufgabe darin, Bestände zu identifizieren und zu beschreiben, wie sich in den Biblioteheken vorfinden". Og videre: "Ihre Aufmerksamkeit gilt den Bestandsgruppen als jenen grösseren Einheiten, deren Ensemble den Charakter einer Bibliothek ausmacht, ihre Eigenart konstituiert und ihre besondere Leistungsfähigkeit begründet." Sådan redegøres der beundringsvist præcist for projektets sigte. Når projektet til sin tid er afsluttet (efter planerne i de tidlige 90ere), vil der komme til at foreligge et opslagsværk med en detaljeret beskrivelse af op mellem 800 og 1.000 tyske biblioteker og deres samlinger, lige fra store af national betydning til mindre stads-, kirke- og skolebibliotekers.

"Handbuch der historischen Buchbestände" er planlagt disponeret således, at hvert hovedafsnit præsenterer de enkelte Länder med deres relevante biblioteker i alfabetisk rækkefølge. (Det drejer sig i den oprindelige projektbeskrivelse kun om Vesttyskland, men efter foreningen af de to Tysklande udvides kredsen selvsagt til hele Tyskland.) Projektets grundstok, nemlig beskrivelserne af det store antal udvalgte biblioteker i de enkelte Länder og deres bogsamlinger, styres og administreres af regionalredaktioner. Således er redaktionen for Nordtyskland (Schleswig-Holstein, Bremen, Hamburg, West-Berlin og Niedersachsen) lagt i hænderne på Herzog August Bibliothek i Wolfenbüttel, og de øvrige regionalredaktioner findes i Köln (NordrheinWestfalen), Frankfurt a.M. (Hessen og Rheinland-Pfalz), Freiburg (BadenWürttemberg og Saarland) og München (Bayern). Af disse fem involverede biblioteker har således tre $\mathrm{i}$ forvejen fået nationalbiblioteksstatus, jvf. ovenfor.

Der er af hovedredaktionen af "Handbuch" lagt en stram og klar disposition for kerneafsnittene med beskrivelserne af de enkelte biblioteker og deres samlinger. Efter et indledningsafsnit, hvor det pågældende bibliotek præsenteres (administrative oplysninger i en fastlåst rækkefølge såsom bibliotekets navn, adresse, telefon, telex, funktion, åbningstider m.v.), følger en $\mathrm{Be}$ standshistorie med sammenhængende redegørelse for bibliotekets historie lige fra dets grundlæggelse, med vægt på en grundig omtale af de i det pågældende bibliotek i tidens $1 \varnothing b$ inkorporerede andre biblioteker og samlinger.

Derpå følger en Bestandsbeskrivelse. Den skal indeholde nøjagtige oplysninger, der er relevante ud fra en konkret bibliotekarisk og videnskabelig 
synsvinkel. Dette kerneafsnit har følgende underafsnit: (a) En kronologisk oversigt, hvor det numeriske omfang af det pågældende biblioteks ældre bogbestand opgøres i fysiske enheder (ikke titler), fordelt på perioderne 15., 16., 17., 18., og 19. århundrede. (b) En oversigt efter sprog indenfor perioderne, hvilket også skal markere det pågældendes biblioteks fremmedsprogede (dvs. ikke-tyske) dækning. (c) En systematisk oversigt på grundlag af bibliotekets egne systematiske kataloger. Her opg øres ligeledes det numeriske omfang af bogbestanden (i fysiske enheder), men denne gang fordelt på fag eller faggrupper. Samlingerne beskrives så detaljeret som muligt inden for rammerne af systematikken. (d) En oversigt over sarsamlingerne, dvs. samlinger, der er opstillet for sig på grund af deres særlige præg, såsom inkunabler, postinkunabler, disputatser, skoleprogrammer, rara o.lign. (e) Bestandsbeskrivelsen slutter med et afsnit om bøgernes Bevaringstilstand.

Det næste hovedafsnit indeholder en fortegnelse over det pågældende biblioteks Kataloger over de historiske samlinger, herunder også kataloger, der ikke længere spiller nogen aktuel rolle som brugsredskaber. Der afsluttes med to i det væsentlige bibliografiske afsnit: Om Kilder og fremstillinger af bibliotekets historie, og om Offentligg $\emptyset$ relser om samlingerne, hvormed menes litteratur om bestemte samlinger og udstillingskataloger.

Hvad der tæller (og skal optælles!) er monografier, tidsskrifter og ephemera, dvs. aviser og småtryk. (Håndskrifter interesserer ikke i denne sammenhæng.) Der må unægtelig til udfærdigelse af de kronologiske, sproglige og systematiske underafsnit af Bestandsbeskrivelseen være knyttet nogle metodiske problemer vedr. optællingsteknik! Derfor skal der før den egentlige Bestandsbeskrivelse være en "Vorbemerkung" om, hvordan man har valgt at tælle. For små biblioteker og samlingers vedkommende vil det være overkommeligt at foretage minutiøs optælling af de fysiske enheder, men for st $\varnothing \mathbf{r}$ re må man nøvendigvis vælge deloptælling med efterfølgende "Hochrechnung".

Det færdige produkt, som forudses at udkomme i 10-12 bind, vil naturligvis være forsynet med fyldige registre.

\section{Handbuch deutscher historischer Buchbestände in Europa}

Dispositionen for det opslagsværk over tyske bibliotekers historiske bogsamlinger, der vil blive produktet af Fabians oprindeligt snævert tyske projekt, er i det foregående skildret så relativt udførligt, fordi samme disposition skal gå igen i aflæggeren "Handbuch deutscher historischer Buchbestände in Euro- 
pa". Naturligvis med visse modifikationer, for de tyske bibliotekers historiske samlinger rummer naturligvis først og fremmest bøger udgivet i Tyskland (og andre tysksprogede områder) og på tysk, mens biblioteker uden for Tyskland kun som randområde rummer bøger af tysk eller tysksproget proveniens. Men under alle omstændigheder er det også sigtet med det "europæiske" projekt at få registreret samlinger med tryk op til 1900, der dels er udgivet i Tyskland, på tysk eller på andre sprog end tysk, dels bøger på tysk, udgivet uden for Tyskland.

Opbygningen af de to opslagsværker (eller måske bedre: de to dele af samme projekt) er altså principielt den samme. Hvad udførligheden af de oplysende beskrivelser angår, overgår naturligvis den tyske del den europæiske, inkl. den danske. For de ikke-tyske bibliotekers tyske historiske bestanddele er det iøvrigt væsentligt, at disse sættes i sammenhæng med den gennem tiderne for det pågældende bibliotek rådende samletradition.

\section{Den danske medvirken i projektet}

Som allerede nævnt ovenfor modtog overbibliotekar Erland Kolding Nielsen i juli 1989 en opfordring fra professor Fabian til Det kongelige Bibliotek om at deltage i den europæiske forlængelse af det oprindeligt tyske projekt. Samme måned fik Fabian et ja til indbydelsen. Der blev udpeget en dansk redaktionskomité bestående af overbibliotekaren (formand), seniorforsker, cand.mag. Harald Ilsøe og bibliotekskonsulent, dr.theol. Jakob H. Grønbæk. I oktober og november kom Fabian til København, hvor han nærmere informerede den udpegede redaktionskomité om projektet, og de grove retningslinjer for det blev afstukket. På Fabians anbefaling sendte overbibliotekaren så i marts 1990 en ansøgning til Volkswagen-Stiftung om kr. 300.000 som $\emptyset$ konomisk støtte til det danske projekt. Og i maj måned meddelte Volkswagen-Stiftung, at bevillingen var givet.

Til projektet i Danmark, der organiseres igennem Det kongelige Bibliotek, har den nedsatte redaktionskomité planlagt at søge inddraget følgende biblioteker: Danmarks Natur- og Lægevidenskabelige Bibliotek, Danmarks Veterinær- og Jordbrugsbibliotek, Kunstakademiets Bibliotek og Statsbiblioteket. Dertil de endnu eksisterende stiftsbiblioteker, samt Herlufsholms Skolebibliotek og Karen Brahes Bibliotek. Flere biblioteker kan også komme på tale.

I august 1990 kunne det forberedende projektarbejde på Det kongelige Bibliotek konkret tage sin begyndelse. Bibliotekar Birgit Stauning blev knyttet til projektet som bibliotekarisk medarbejder, og efter nogle planlægnings- 
møder i redaktionen påbegyndte Birgit Stauning i samarbejde med Jakob H. Grønbæk planlægningsarbejdet i forbindelse med den forudsigeligt komplicerede registrering og optælling af Det kongelige Biblioteks samlinger.

Det blev under overvejelserne vedr. tilrettelæggelsen af dette arbejde anset for hensigtsmæssigt at sætte ind med udarbejdelse af kerneafsnittet: $B e$ standsbeskrivelsen (se ovenfor). Og det forekom helt naturligt at sætte ind med den ældre udenlandske hovedsamling (ÆS), der indeholder bøger fra bogtrykkerkunstens opfindelse til og med 1949. Det er også her, man først og fremmest vil finde de tyske bøger. Som platformen for registerings- og optællingsarbejdet benyttes Ældre Samlings Systematiske Katalog ("Moldenhawer"), hvor bøgerne i den udenlandske hovedsamling, i den rækkefølge de (med relativt få undtagelser) er opstillet i magasinerne, er blevet indført i hånden titel på titel siden begyndelsen af forrige århundrede.

Når optællingen i de ældre udenlandske og dernæst de ældre danske samlinger var tilendebragt, skulle der således komme til at foreligge en tilnærmelsesvis nøjagtig numerisk opgjort beskrivelse af Det kongelige Biblioteks ældre bogbestand op til o. 1900, fordelt på følgende af det internt tyske projekt bestemte underafsnit:

(a) En oversigt over, hvor mange bøger (fysiske enheder) biblioteket rummer, fordelt på perioderne 15., 16., 17., 18. og 19. århundrede.

(b) En oversigt efter sprog inden for disse perioder, hvilket først og fremmest skal tilsigte at konstatere den tyske dækning, dvs. hvor mange bøger (fysiske enheder) der i disse århundreder er tyske, dvs. udgivet i Tyskland og andre tysksprogede områder på tysk eller på et andet sprog. Dertil kommer yderligere en 3. kategori, nemlig bøger på tysk udgivet uden for tysksprogede områder; antallet af sådanne bøger viste sig imidlertid tidligt under optællingen i de udenlandske samlinger at være så ubetydeligt, at denne kategori blev droppet her. Den slags tyske bøger spiller derimod en indlysende rolle i de danske samlinger.

(c) En samlet fagdelt oversigt med udgangspunkt i gældende systematik af samlingerne.

(d) En oversigt over de ældre (historiske) særsamlinger.

(e) En oversigt over de ældre bøgers bevaringstilstand.

\section{Om optællingen - metode og nogle resultater}

Ultimo juli 1991, altså næsten nøjagtig et år efter projektarbejdets begyndelse, er vi nået så vidt, at Birgit Stauning har tilendebragt optællingen af de 
fysiske bogenheder i såvel de ældre udenlandske som de ældre danske samlinger. Og dermed skulle materialet i princippet ligge klart til den afsluttende udarbejdelse af bestandsbeskrivelsens underafsnit (a) til (d).

Det var naturligvis altafgørende på forhånd at få styr på, hvorledes selve optællingen skulle ske. Af det rette valg af tællemetode (-teknik) afhang indlysende nok ikke blot projektets ressourcemæssigt overkommelige afvikling, men fremfor alt også projektresultatets troværdighed. Den af Birgit Stauning valgte og af redaktionen godkendte fremgangsmåde skal kort fremlægges i det følgende.

For at illustrere fremgangsmåden skal i det følgende kort redegøres for, hvorledes teologien i den aldre udenlandske hovedsamling blev optalt. Dette fag står i spidsen i "Moldenhawer" og blev naturligt også det første af fagene, der blev taget under behandling. Således blev teologien også prøveklud og model for den videre tælleproces, der satte ind med de øvrige fag eller fagområder. Og før selve optællingen var der på forhånd foretaget en hensigtsmæssig opdeling af den udenlandske hovedsamlings fagområder med udgangspunkt i "Moldenhawer"s systematiske grupper, der i flere tilfælde blev omstillet, brudt op eller trængt sammen.

Teologien er indeholdt i protokolkatalogerne 1-5 (folianter), 20-32 (kvarter) og 82-89 (oktaver), ialt 36 kataloger på - som det viste sig - 11.253 sider. (Det skal lige bemærkes, at disse kataloger ikke rummer hele teologien, således f.eks. ikke enkelte lande og områders kirkehistorie, der findes i historiekatalogerne, teologisk filosofi, som findes i filosofikatalogerne, og teologers samlede værker, som findes i katalogerne over samlede værker.)

Naturligvis ville det have været urealistisk inden for de afstukne ressourcerammer at foretage en finoptælling af hele teologien! Totalantallet på bind (fysiske enheder) i faget $\mathrm{i}$ udenlandske ældre samling viste sig at være 57.387, omfattende bøger fra 1501 til 1900. (15. århundredes inkunabler er foreløbig ikke medregnet.) Dette totaltal på den teologiske bogbestand, fordelt på perioder og sprog (tysk og ikke-tysk), blev opnået på følgende måde:

(1) Til en finoptcelling blev udvalgt kataloger, der skønnedes repræsentative for alle tre formater. Under nøje inddragelse af, hvor mange fysiske enheder de håndskrevne titler omfattede, blev disse skematisk fordelt på følgede kategorier:

Perioder (16., 17., 18. og 19. årh.)

Tysk I (på tysk, udgivet i Tyskland)

Tysk II (på andre sprog end tysk, udgivet i Tyskland)

Tysk ialt (med senere angivelse i procent af totalen)

Andre

Total 
Finoptællingen omfattede 7 kataloger med ialt 1.647 sider af totalsideantallet 11.253 for hele teologien, altså 14.63 procent. (En måske lovlig lille procentdel, som derfor også for de efterfølgende optalte fag blev hævet til mellem 25 og 30.)

(2) Den minutiøse optælling af - for at tage et illustrerende eksempel "Tysk I" og "Tysk II" = "Tysk ialt" $i$ 16. århundrede resulterede i 646 bind (fysiske enheder). Dette tal brugtes som udgangspunkt (fordelingstal) til fastsættelse af, hvor mange tyske bøger fra 16. århundrede hele teologien (dvs. alle "Moldenhawer"s 36 kataloger) rummede. Som nævnt omfattede de finoptalte kataloger 1.647 sider, dvs. at der pr. side gennemsnitligt var 0,392228 tyske bøger fra 16 . århundrede. Dette tal blev ganget med det samlede antal sider i alle de teologiske kataloger, nemlig 11.253. Det gav ialt 4.414 bøger, som viste sig at være 51,31 procent af samme århundredes total (8.602 bind).

(3) På samme måde beregnedes tallene for hele teologien inden for hvert århundredes kategorier med udgangspunkt i finoptællingen af de udvalgte kataloger. Derved opnåedes til sidst i optællingen slutresultatet for hele den teologiske bogbestand i den ældre udenlandske samling, således som den er registreret i "Moldenhawer", nemlig de allerede ovenfor nævnte 57.386 bind (fysiske enheder) og den tyske procentandel: 53,17.

(4) Efter optællingen af teologien fortsattes med de фvrige fag (og fagområder) på grundlag af "Moldenhawer", og ved addering af alle fagenes fysiske bogenheder, som var fordelt på århundreder og sprog, nåedes (endelig) sluttallene med henblik på, hvad hele den celdre udenlandske hovedsamling indeholder af bogudgivelser 1501-1900. Tallet blev 383.849 bind (fysiske enheder), heraf repræsenterede 168.997 bind den ældre tyske bogproduktion, altså 44,03 procent.

Den totale ældre udenlandske bogbestand 1501-1900 er opgjort til at omfatte ialt 425.482 bogenheder, heraf tysk 221.482 , altså 52,05 procent. Her er foruden hovedsamlingen også medtaget de bøger, man ikke nåede at indføre i "Moldenhawer", før den blev lukket (ca. 3.400 bind), dertil aviser (ca. 776 bind), disputatser, der ikke figurerer i "Moldenhawer" (32.161) og rektortaler m.v. (4.856).

Principielt på samme måde som de udenlandske samlinger er de danske blevet optalt i nationalbibliotket. Altså med udgangspunkt i en systematisk faglig opdeling og med fordeling på perioder og sprog (her tysk/dansk). Optællingen fandt imidlertid ikke sted $\mathrm{i}$ de håndskrevne kataloger over den ældre danske bogbestand (til og med 1959), men i den trykte nationalbibliografi (Bibliotheca Danica) med supplementer, der medtager litteratur fra den 
ældste tid og til 1840 fra om om Danmark i videste forstand, inkl. Norge (indtil 1814), Island, Grønland og Slesvig-Holsten (indtil 1864). Det vil her føre for vidt at komme ind på en detaljering af grundlaget for optællingen ud over Bibliotheca Danica med supplementer (det er også temmelig kompliceret), men for årene 1841-1900 er naturligvis først og fremmest Dansk Bogfortegnelse grundlaget. Nævnes skal det, at en på foranledning af daværende overbibliotekar Chr. Bruun i 1874 og 1875 foretaget optælling af Det kongelige Biblioteks bogbestand (jvf. Aarsberetninger 1876) har været en meget nyttig kontrolinstans.

Dertil skal føjes, at det i projektets tyske sammenhæng særdeles vigtige område Slesvig-Holsten (i dag principielt identisk med den tyske delstat Schleswig-Holstein) optællingsmæssigt har været ret kompliceret. Dette område dækkes indtil 1830 af Bibliotheca Danica med supplementet Bibliotheca Slesvico-Holsatica, der ydermere dækker tiden op til 1840. For tiden 18411900 har Birgit Stauning konsulteret den såkaldte "omarbejdelse" (jvf. Åse Reymanns artikel om denne danske seddelkatalog i Magasin, 3. årg. nr. 2, 1988, s. 27ff).

Endelig skal der for Slesvig-Holstens vedkommende tilføjes, at årstallet 1864 danner skel med hensyn til den sproglige kategoribestemmelse. Den for optællingen af den ældre danske bogbestand gældende 3. kategori "Tysk III" (bøger på tysk udgivet uden for tysksproget område) omfatter - som for bøger overhovedet, der hører til nationalbibliotekets samlinger - også SlesvigHolsten før 1864 (ligesom tilfældet er for Norge før 1814), mens den samme art bøger efter 1864 henhører til og er optalt under "Tysk I" (bøger på tysk udgivet inden for tysksproget område).

Resultatet af optællingen af de danske samlinger blev, at omfanget af den del af nationalbibliotkets bogbestand, der dækker 1501-1900, udgør 175.608 bind, fordelt på perioder og sprog ("Tysk I", "Tysk II", "Tysk III", "Tysk ialt", "Andre" = danske og "Total"). Heraf udgør den tyske andel ("Tysk ialt") 30.145 bind, dvs. 17,17 procent.

Tilbage står nu for Det kongelige Biblioteks vedkommende vist "kun" numerisk at medregne de allerede optalte inkunabler (mange i udenlandske samlinger, men ikke i danske!), at opgøre den tyske andel i Det kongelige Biblioteks hebraica og judaica og at optælle den ældre bogbestand p̊ Universitetsbiblioteket i Fiolstræde. Den danske andel i Fabian-projektet forudsættes afsluttet medio 1992. Til den tid skulle den del af "Handbuch deutscher historischer Buchbestände in Europa" ligge klar, omfattende Det kongelige Bibliotek og andre danske biblioteker med væsentlige ældre tyske bestanddele i deres samlinger. 


\section{Hvad får Det kongelige Bibliotek ud af projektet?}

Afslutningsvis blot nogle få og foreløbige overvejelser om nytteværdien for Det kongelige Bibliotek af beskæftigelsen med Fabian-projektet og af det færdige produkt, der kommer ud af det.

For dem, der ikke har glemt, at Det kongelige Bibliotek rummer en meget værdifuld og i flere henseender unik skat af ældre bøger, er det kærkomment, at et projekt retter søgelyset mod den del af vort gamle biblioteks samlinger. Der har været en dominerende tendens, som naturligvis i disse moderne tider er dikteret af ressourceknaphed, til kun at fokusere på det nære. Men der har også vist sig flere tegn i tiden på, at traditionen, rødderne, historien ikke bør forsømmes. Fabian-projektet kan betragtes som et sådant tegn, og vi skal byde det velkommen. Det kongelige Bibliotek har heldigvis også gjort det! Fabian-projektet har givet os en kærkommen anledning til fornyet at beskæftige os med bibliotekets ældre samlinger.

En fornyet og grundig beskæftigelse med noget, giver altid ny indsigt. Det gælder også den fornyede beskæftigelse med de ældre samlinger. Blandt nye - interessante og nyttige - indsigter kan i flæng nævnes et par stykker.

At det tyske har spillet en meget væsentlig rolle i den danske kulturs og videnskabs historie, er ingen hemmelighed. Det kongelige Bibliotek reflekterer ved den skiftende indkøbspraksis også den kulturelle udvikling. Takket være Fabian-projektet kan vi nu få syn for sagn, hvad angår den tilnærmelsesvis nøjagtige tyske andel i den ældre bogbestand, fag på fag, århundrede på århundrede.

Nævnes kan også, at der - siden Chr. Bruuns optælling i 1874 og 1875 ingen sikkerhed har rådet, når det drejede sig om at bestemme det nøjagtige omfang af de udenlandske ældre samlinger. Før man satte ind med en totalrevision i slutningen af $1970 \mathrm{erne}$, måtte man således foretage et skøn af hensyn til bestilling af stregkodeetiketter. Men skønnet ramte ikke så lidt ved siden af! Efterhånden som revisionen er skredet frem, er man imidlertid kommet på sikrere grund. Naturligvis er der nu draget omsorg for, at ikke blot de bøger op til 1900, Fabian interesserer sig for, er blevet optalt i hele Ædre Samling, men hele samlingen (til og med 1949). Og det tal, vi (dvs. Birgit Stauning) er nået frem til, ligger meget nær på det i dag af Revisionsafdelingen skønnede. Når revisionen endelig er afsluttet - det kan ske på godt 5 år med en ikke-reduceret bemanding! - kommer det nøjagtige tal til at foreligge. (Iøvrigt skal det fremhæves, at revisionens nummeretiketter har været overordentlig befordrende for optællingens tempo og grundighed.)

Endnu kan nævnes, at Det kongelige Bibliotek - det kom konkret for dagen under optællingsarbejdet - er i besiddelse af meget værdifulde og særde- 
les omfattende disputatssamlinger, som hidtil har været lidet påagtede, og som især rummer tyske disputatser helt tilbage til 1500-tallet, hvoraf over 10.000 er på latin. Denne samling vil - det er planlagt - efter projektarbejdets afslutning blive gjort til genstand for en edb-baseret registrering.

Ovenstående præsentation af Fabian-projektet er skrevet i stadig kontakt med bibliotekar Birgit Stauning, som takkes for en utrættelig indsats. 